\title{
A desmedida do capital
}

LINHART, Danièle. Tradução de Wanda Caldeira Brant. São Paulo: Boitempo, 2007. 248 p.

Ao publicar o instigante livro A desmedida do $\mathrm{ca}^{-}$ pital, da socióloga francesa Danièle Linhart ${ }^{1}$, a Editora Boitempo brinda pesquisadores e estudiosos do mundo do trabalho. Por meio de uma coletânea formada por diversos artigos que versam sobre as transformações na organização e na gestão do trabalho na empresa moderna, Linhart discorre sobre o tema a partir de maio de 1968 até os dias atuais, articulando o posicionamento teórico de diversas correntes no âmbito da sociologia do trabalho às inúmeras pesquisas empíricas que realizou ao longo de sua carreira internacionalmente reconhecida.

A indagação presente em toda a obra refere-se às implicações na sociedade provenientes das alterações no trabalho. A argumentação é iniciada tomando como ponto de partida o ano de 1968, momento histórico da maior relevância para a França, quando, por meio da organização coletiva de operários e estudantes, foram conquistados novos direitos e, ao mesmo tempo, criaram-se as condições para que não só aflorasse a heterogeneidade da classe operária, mas para que os próprios trabalhadores se reconhecessem enquanto atores heterogêneos, com diferentes características e diversas reivindicações.

O período de 1968 a 1975 é denominado pela autora como o "tempo de recusa", marcado por movimentos grevistas, altos índices de absenteísmo e de rotatividade. A análise das palavras de ordem, dos muros pichados remete, para alguns pesquisadores, a um processo de distanciamento do trabalho entre os mais jovens, emergindo aspectos fundamentalmente negativos e enfocando o trabalho apenas como fonte de sobrevivência financeira, refratário a qualquer valor. O que teria preenchido o espaço até então ocupado pelo trabalho? Deste questionamento surge outra corrente teórica, que buscará abordar as formas de preservação do emprego, contrapondo-se frontalmente à concepção do trabalho como fonte exclusiva de "ganhar a vida", relembrando as palavras de ordem de maio de 1968.

Para a autora, tratar o trabalho meramente como uma contingência econômica e desprovida de realização limita a compreensão das relações sociais que o envolvem, reduzindo-o a uma análise pautada estritamente na racionalidade econômica. Para Linhart, tal perspectiva rende-se ao capital e desconsidera a possibilidade de emergir um debate político capaz de construir novos conceitos.
Danièle segue, na segunda parte do livro, contextualizando o trabalho em seu momento histórico, apresentando quatro artigos que focalizam os anos 1980 na França, caracterizando-o como a "era da mudança”. Nesse período, o governo socialista de François Mitterrand expõe sua intenção de ampliar as formas de participação dos trabalhadores nas empresas, dando legitimidade, gradualmente, a essas mesmas empresas, que buscavam maiores índices de produtividade. O movimento sindical, na época, apontava o imperativo de avançar em direção a questões mais relevantes, há tempos relegadas por governos anteriores. Nesse clima de debate político, o patronato seguiu experimentando suas próprias "formas de humanização” no trabalho, implantando, por exemplo, os círculos de qualidade, que, em princípio, ampliavam a participação, mas que, no entanto, assemelhavam-se ao proposto por Taylor, que premiava a sugestão de aperfeiçoamentos ao processo de trabalho, com conseqüentes aumentos de produtividade.

As transformações nas denominações das ocupações revelam um teor ideológico voltado à valorização das competências em lugar das qualificações. Os faxineiros passam, na França, a serem denominados "técnicos de superfície". No Brasil, diretores de escolas públicas são, agora, "gestores", reafirmando um caráter mais gerencial e distante das discussões em torno da educação. Um outro exemplo: teleatendentes que atuam na intermediação da força de trabalho são denominados "consultores de recursos humanos".

Essas alterações foram compreendidas por pesquisadores, a exemplo de Veltz e Zarifian (Vers de nouveaux modeles productifs. Sociologie du Travail, n. 1, 1993), como uma era pós-taylorista, considerando que o trabalho torna-se cada vez menos prescritivo e os trabalhadores mais autônomos e responsáveis. Danièle faz sua opção analítica elegendo três esferas, a fim de analisar os modelos organizacionais. Em primeiro lugar, pondera que a "empresa piramidal” está longe de ser superada, situação passível de observação tanto em setores tradicionais da economia, como o financeiro, quanto em novos setores, como o do teleatendimento, cuja pirâmide quadrangular é a representação imagética das limitações de ascensão na carreira. Em segundo, as "relações sociais", questionando o recorrente discurso empresarial, que apresenta como sua grande riqueza "seus homens", seguindo o percurso da pseudovalorização do potencial individual na obtenção de melhores resultados e de maior responsabilização, comumente

\footnotetext{
${ }^{1}$ Danièle Linhart é pesquisadora do Laboratório Genre, Travail et Mobilités, professora da Université Paris X - Nanterre e autora de diversos livros, entre os quais Le torticolis de l'autruche (1991); La modernisation des entreprises (1994) ; Le travail nous est compté: la construction des normes temporelles du travail (2005).
} 
solitária nos momentos de resolução de um problema; e, por fim, a "organização do trabalho", dividida pela autora em três práticas: as que rompem com alguns princípios tayloristas, as que o fortalecem e as que reproduzem antigos modelos, esta última prevalecendo na França e demonstrando que permanece um "déficit de confiança entre diretorias e executores” (p. 102) e, portanto, difícil de ser suplantado.

Esses aspectos somam-se à intencionalidade, por parte das empresas, de reduzir a influência dos coletivos sobre os trabalhadores na tentativa de concretizar um pertencimento a outra "comunidade produtiva", a empresa capitalista. Para Linhart, o sindicalismo francês, no final do século XX, é pouco atraente aos jovens trabalhadores e distanciou-se da luta pelo emprego, da defesa por melhores salários e, ainda mais, da interferência nas alterações na organização do trabalho. Qual seria, então, o papel anunciado aos sindicatos no enfrentamento de condições adversas pelo conjunto de trabalhadores? Esta inquietação está presente de forma direta e indireta nos textos de Danièle Linhart: como será ocupado o espaço cada vez mais vazio do coletivo? As negociações passarão a ser individuais e não mais coletivas?

Se a resposta for afirmativa, será o corolário das práticas gerenciais em curso, proliferando atitudes individualizantes. As empresas almejam por trabalhadores desenraizados e "alforriados" dos seus respectivos coletivos tradicionais. Desta forma, a sociedade está ameaçada de se submeter à "hegemonia cultural da empresa” (p. 126) - se tal debate não for promovido entre trabalhadores e a sociedade em geral.

O livro expõe uma pesquisadora inquieta, indignada com o alcance da chamada "empresa moderna", especialmente com os possíveis rumos que conduzirão jovens trabalhadores submetidos à cooptação da subjetividade, de forma cada vez mais refinada e com frágeis referências coletivas para ações de resistência.

Mas não poderíamos finalizar esta resenha sem expor a questão que deve preponderar na consciência dos leitores brasileiros dessa coletânea: se a perplexidade de Danièle Linhart fica estampada neste livro que retrata a França nos últimos quarenta anos, quais questionamentos podem ser elaborados para as relações de trabalho no Brasil, tradicionalmente mais flexíveis e com organizações coletivas menos estruturadas quando comparadas às francesas?

Selma Venco

Pesquisadora-colaboradora do Instituto de Filosofia e Ciências Humanas da Universidade Estadual de Campinas (Unicamp). selmavenco@uol.com.br 